\title{
The Influence of Peer Assessment and the Use of Corpus for the Development of Speaking Skills in In-Service Teachers
}

\section{La influencia de la co-evaluación y un corpus en el desarrollo de la habilidad oral de docentes en ejercicio*}

\author{
Mary Mily Gómez Sará \\ marygomsa@unisabana.edu.co \\ Universidad de La Sabana, Bogotá, Colombia
}

This article reports on how the use of peer-assessment and a corpus influence the development of the spontaneous interactive speaking of 14 adults with an A1 English level. The data, that were collected through video recordings, two peer-assessment forms, and a teacher's journal, evidenced the development of three enhancement strategies (willingness to improve, use of compensatory strategies, and construction of a personalized version of the corpus) and two detrimental traits (underassessment and dependency on the corpus).The results of the inquiry evinced some limitations in the pedagogical intervention.

Key words: Corpus, in-service teachers, peer assessment, spontaneous interactive speaking.

Este artículo informa sobre cómo el uso de la evaluación por pares y un corpus influyen en el desarrollo del habla espontánea interactiva de 14 adultos con nivel A1 de inglés. Los datos, que fueron recogidos a través de videograbaciones, dos formatos de evaluación por pares y un diario del docente, evidenciaron el desarrollo de tres estrategias de mejoramiento (voluntad de mejorar, uso de estrategias compensatorias y construcción de una versión personalizada del corpus) y dos rasgos perjudiciales (in-

* $\quad$ Received: July 17, 2015. Accepted: February 22, 2016.

How to cite this article (APA 6th ed.):

Gómez Sará, M. M. (2016). The influence of peer assessment and the use of corpus for the development of speaking skills in in-service teachers. HOW, 23(1), 103-128. http://dx.doi.org/10.19183/how.23.1.142.

This article is licensed under a Creative Commons Attribution-NonCommercial-NoDerivatives 4.0 International License. License Deed can be consulted at http://creativecommons.org/licenses/by-nc-nd/4.0/. 
fravaloración y dependencia al corpus). Los resultados de la investigación evidenciaron algunas limitaciones en la intervención pedagógica.

Palabras clave: corpus, docentes en ejercicio, evaluación por pares, habla espontánea interactiva.

\section{Introduction}

This paper describes a research study conducted with a group of in-service school teachers in different content areas who were studying English to enrich their professional performance. The research question that guided the development of the study was: "How might the use of two peer assessment strategies and a corpus influence the development of the spontaneous interactive speaking of a group of 14 adults with an A1 English level?’ In the subsequent pages, the reader will find the process that the teacher-researcher went through when undertaking and conducting the study.

\section{Identification of Participants'Learning Needs}

Identifying the learning needs of participants was relevant in order to set their learning objectives and decide on an action plan. Two questionnaires and a focus group were used to explore participants' linguistics, affective, and cognitive needs as follows:

- Through Questionnaire 1 (Appendix 1) and focus group (Appendix 2), participants reported that they had difficulties producing oral language, especially in spontaneous situations that entail interacting with others. This was interpreted as their linguistic need.

- Through the Questionnaire 2 (Appendix 3), participants reported that comforting students who were having problems or were going through difficult circumstances, was the most common communicative situation that they faced in their work as schoolteachers when interacting with their students outside the classroom context. This suggested that their affective need had to do with establishing rapport with their students by supporting them.

- Through Questionnaire 1, participants also reported that the class time was not enough for practicing and improving their English. This suggested that their cognitive need had to do with developing autonomous learning skills that would allow them to extend their language practice beyond the face-to-face classes.

\section{Strategies Proposed to Address Participants' Needs}

To attend to participants' cognitive need, two peer-assessment strategies (checklist [Appendix 4] and Plus, minus, and what's next? [Appendix 5]) were selected in order to foster autonomous learning. 
The Influence of Peer Assessment and the Use of Corpus for the Development of Speaking Skills in In-Service Teachers

Peer assessment checklist. The peer assessment (PA) checklist was used to encourage participants to reflect on their strengths and weaknesses in speaking by contrasting their productions with criteria of satisfactory performance. Thus, the strategy was intended to help participants raise awareness of their English language learning process, which is necessary to foster autonomous learning. The PA checklist was also used as a data collection instrument.

Plus, minus, and what's next? The "Plus, minus, and what's next?" (PMWN) was used to encourage participants to reflect on their strengths, weaknesses, and improvement opportunities using their own words instead of pre-established criteria as in the checklist. The strategy was intended for participants to become more critical when reflecting on their oral performance, which is also necessary to foster autonomous learning. According to Glasson (2009), the PMWN is a strategy in which learners reflect on what was done well (plus) and wrong (minus) in regard to the development of a particular task. Then, they generate a personal learning target (what's next?). For the purpose of the present study, participants had to write their perceptions about their peers' spoken strengths and weaknesses when developing speaking tasks. Furthermore, instead of producing a personal learning target, they had to write improvement pieces of advice to their classmates. The PMWN was also used as a data collection instrument.

Corpus. To attend to participants' linguistic and affective needs the teacher-researcher selected to teach participants a corpus (Appendix 6) with the most common expressions used to comfort someone. According to Bennett (2010) and Suzuki (2008, 2009a, 2009b, 2010, 2011), a "corpus" is a tool that informs the frequency of use of words and/or combination of words. Thornbury (2008), Moudraia (2001), and Suzuki (2008, 2009a, 2009b, 2010, 2011) believe that learning prefabricated multi-word units (also known as chunks) help learners produce more fluent and accurate language because they do not have to think about sentences word by word, but in longer meaningful units. According to Moudraia (2001), "the lexical approach to second language teaching [which consists of teaching prefabricated multi-word units to L2 learners] has received interest in recent years" (p. 1), so it deserves to be studied in order to explore its influence and features. Moreover, teaching participants to comfort their students in English would enrich their professional performance.

\section{Literature Review}

\section{Peer Assessment for Developing Oral Skills}

The teacher-researcher contrasted three studies in which PA to foster the development of speaking skills in English language learners was used. The first study was conducted in Iran (Ahangari, Rassekh-Alqo, \& Akbari, 2013), the second one was carried out in Spain (Serrano \& Cebrián de la Serna, 2011), and the last one was developed in Colombia (Gómez, 2014). As 
a result of contrasting the studies, the teacher researcher could have an idea of what have been done around the globe in regard to the use of PA to foster speaking development. Table 1 summarizes the findings of the three studies in terms of positive effects, negative effects, and other findings and recommendations.

Table 1. Peer Assessment for Developing Oral Skills

\begin{tabular}{|c|c|}
\hline Positive Effects of PA & Negative Effects of PA \\
\hline $\begin{array}{l}\text { - It fosters involvement, responsibility, and } \\
\text { commitment in students. } \\
\text { - Students raise awareness of their learning process } \\
\text { and skills. } \\
\text { - Students become able to assess their peers similar to } \\
\text { their teachers. } \\
\text { - It fosters autonomy and critical thinking. } \\
\text { - Learners liked and enjoyed it. } \\
\text { - It positively influences self-assessment. } \\
\text { - Students praise and reinforce their peers' good } \\
\text { performance. }\end{array}$ & $\begin{array}{l}\text { - Students found evaluating their peers' speaking and } \\
\text { learning abilities difficult. } \\
\text { - Under and over assessment were frequent. } \\
\text { - It requires the support of other techniques to } \\
\text { encourage reflection. }\end{array}$ \\
\hline \multicolumn{2}{|c|}{$\begin{array}{l}\text { Other Findings and Recommendations } \\
\text { - The intermediate level of students was found to be an advantage when applying PA. } \\
\text { - Discussion and reaching agreements on the assessment criteria are recommended to help learners internalize } \\
\text { the criteria. }\end{array}$} \\
\hline
\end{tabular}

\section{Teaching Through Prefabricated Chunks}

Chu and Wang (2011) review the role that the lexical chunk method, which consists of teaching learners prefabricated lexical chunks, has had on the development of the oral and written competences of Chinese students who learn English as a foreign language. Their review reveals that the method contributes to the enhancement of learners' pragmatic competence, helps students understand the discourse structures and speech rules, and promotes fluency and accuracy in oral and written English. However, Chu and Wang (2011) pointed out that a disadvantage is that chunks are learned as unanalyzed units that are not available to be combined with other structures or parts and this limits their use.

\section{Research Design}

The study followed the qualitative approach, which according to Creswell (2009) and McMillan and Schumacher (2009) is characterized by in-setting participation and observation, and highly descriptive data. In addition, the inquiry used the action research method, which 
The Influence of Peer Assessment and the Use of Corpus for the Development of Speaking Skills in In-Service Teachers

according to Koshy (2005), Lim (2007), Sagor (2000), and Valcarcel (2009), consists of in-service teachers studying class situations in order to improve their pedagogical practice. Hence, teachers assume a double role as teachers and researchers.

\section{Participants and Context}

This study was conducted with 14 adults, from 26 to 50 years old, who worked as schoolteachers in different content areas (Christian education, mathematics, music, physics, Spanish, social science, accounting, biology, and pre-school education) at a private nonprofit school located in the northeast of Bogota, Colombia. Participants' English level was A1 according to the Common European Framework of Reference (CEFR) (Council of Europe, 2014). In order to become a bilingual institution, the school provided two hours of English training per week for the teaching staff. The 14 teacher-students signed a consent form through which they authorized their participation in the research study.

\section{Data Collection Instruments}

Data were collected through four instruments, namely, video recordings (Appendix 7), PA checklist (Appendix 4), PMWN (Appendix 5), and a teacher-researcher's journal (Appendix 8). The video recordings were used to gather data on participants' speaking behaviors, the PA checklist and PMWN were used to collect data on participants' perceptions towards their peers' spoken productions, and the journal was used to collect data on the teacher-researcher's perceptions on the participants' responses to the pedagogical implementation. Immediately after each session, the teacher-researcher wrote an entry in the journal in order to guarantee that the memories were still fresh.

\section{Pedagogical Intervention}

The pedagogical intervention was carried out in 11 lessons of two hours each (22 hours). It was developed in two stages, namely, training (six hours divided into three sessions) and main implementation (16 hours divided into eight sessions). In the training stage, participants got acquainted with the features, scope, aims, and methodology of the research study. Also, the PA forms and the corpus were introduced and some practice on how to use them was carried out. Then, the main implementation stage was undertaken using task-based instruction (Willis \& Willis, 2012) which consists of learners using authentic language to do meaningful situational tasks.

Thus, at the beginning of each lesson, participants did activities to appropriate the corpus of 69 prefabricated chunks, which was a reconstruction of Suzuki's $(2008,2010)$ comforting corpus. These activities served them as preparation for subsequent tasks in which they had to produce SIS in role-plays about comforting situations such as break up, difficult situations, 
unfavorable events, sickness or injury, failure on a test, accident, or death of a loved one, which Suzuki $(2008,2010)$ recognized as the most common comforting situations occurring in the educational environment.

\section{Data Analysis and Results}

Data were analyzed using the grounded theory approach, which consists of coding data in three consecutive steps, namely, open, axial, and selective (Corbin \& Strauss, 2008). In open coding, data were extracted from the instruments, contrasted, and triangulated. From this procedure, the teacher-researcher obtained a list of recurrent topics (patterns). Then, in the axial coding the patterns were grouped obtaining categories and subcategories. Finally, in the selective coding, the categories were grouped and refined in order to obtain a core category that answered directly the research question and predicted how PA and corpus would operate in diverse contexts. Table 2 shows the steps carried out in the data analysis process.

Table 2. Emerging Patterns, Subcategories and Categories

\begin{tabular}{|c|c|c|c|c|}
\hline \multicolumn{2}{|c|}{$\begin{array}{l}\text { Emerging and Recurrent Topics } \\
\text { (Patterns) }\end{array}$} & Subcategories & Categories & Core category \\
\hline \multirow{3}{*}{$\begin{array}{l}\text { Patterns that } \\
\text { improved } \\
\text { participants' SIS }\end{array}$} & $\begin{array}{l}\text { - Recognition of speaking } \\
\text { strengths and weaknesses } \\
\text { - Identification of } \\
\text { pronunciation, accuracy, } \\
\text { fluency, and linking } \\
\text { words as weakness } \\
\text { - Awareness raising }\end{array}$ & $\begin{array}{l}\text { Willingness to } \\
\text { improve }\end{array}$ & \multirow{3}{*}{$\begin{array}{l}\text { Development of } \\
\text { Strategies to } \\
\text { Enhance SIS }\end{array}$} & \multirow{3}{*}{$\begin{array}{l}\text { Appearance of } \\
\text { strategies to enhance } \\
\text { SIS as well as traits } \\
\text { that limit the } \\
\text { development of SIS }\end{array}$} \\
\hline & $\begin{array}{l}\text { - Comply with the } \\
\text { interaction, volume, } \\
\text { speaking time, variety, } \\
\text { and organization criteria } \\
\text { - Use of compensatory } \\
\text { strategies to interact } \\
\text { - Transference of abilities } \\
\text { from L1 to L2 }\end{array}$ & $\begin{array}{l}\text { Use of } \\
\text { compensatory } \\
\text { strategies }\end{array}$ & & \\
\hline & $\begin{array}{l}\text { Preferences and } \\
\text { personalization of the } \\
\text { corpus }\end{array}$ & $\begin{array}{l}\text { Construction of a } \\
\text { personalized version } \\
\text { of the corpus }\end{array}$ & & \\
\hline
\end{tabular}


The Influence of Peer Assessment and the Use of Corpus for the Development of Speaking Skills in In-Service Teachers

\begin{tabular}{|c|c|c|c|c|}
\hline \multicolumn{2}{|c|}{$\begin{array}{c}\text { Emerging and Recurrent Topics } \\
\text { (Patterns) }\end{array}$} & Subcategories & Categories & Core category \\
\hline \multirow[t]{2}{*}{$\begin{array}{l}\text { Patterns that } \\
\text { limited } \\
\text { participants' SIS }\end{array}$} & $\begin{array}{l}\text { - Underassessment } \\
\text { - Reluctance and } \\
\text { difficulties to give pieces } \\
\text { of advice } \\
\text { - Fear to threaten peers } \\
\text { - Lack of critical thinking } \\
\text { skills and awareness of } \\
\text { the learning process }\end{array}$ & Underassessment & \multirow[t]{2}{*}{$\begin{array}{l}\text { Emergence of } \\
\text { Detrimental Traits }\end{array}$} & \multirow[t]{2}{*}{$\begin{array}{l}\text { Appearance of } \\
\text { strategies to enhanc } \\
\text { SIS as well as traits } \\
\text { that limit the } \\
\text { development of SIS }\end{array}$} \\
\hline & $\begin{array}{l}\text { - Dependency on the } \\
\text { corpus }\end{array}$ & $\begin{array}{l}\text { Dependency on the } \\
\text { corpus }\end{array}$ & & \\
\hline
\end{tabular}

Through the open and axial coding, the teacher-researcher discovered that the use of PA and a corpus produced two main effects on participants' SIS. On the one hand, it encouraged participants to develop strategies to enhance their SIS productions (Category 1). These strategies were called willingness to improve (Subcategory 1.1), use of compensatory strategies (Subcategory 1.2), and construction of a personalized version of the corpus (Subcategory 1.3). On the other hand, it provoked the emergence of two detrimental traits (Category 2) that were named underassessment (Subcategory 2.1) and dependency on the corpus (Subcategory 2.2). Subsequently, the categories and subcategories are explained in detail and supported through excerpts taken from the instruments.

\section{Category 1: Development of Strategies to Enhance SIS}

The use of PA and corpus encouraged participants to develop three strategies to improve their SIS performance.

Subcategory 1.1: Improvement willingness. The teacher-researcher observed a change in participants' assessment patterns by the end of the implementation process. This change had to do with the emergence of willingness to improve the peer assessment practice. By the end of the implementation, participants showed an emergent motivation to express their ideas, produce more objective and less emotional assessment, identify their peers' mistakes and difficulties, and provide specific reasons to support their assessment.

At the beginning of the implementation process, participants were reluctant to express their opinion, especially through the "observations" column of the checklist. Nonetheless, at the end of the implementation, they showed an emergent desire to write 
their opinions. Therefore, they moved from no comment in the checklists to at least two comments, which are shown in Excerpt 1 below: ${ }^{1}$

Excerpt 1. Emergence of Participants' Comments

S10 and S9: very good!

S4: can be better. (Checklist)

Although these comments do not evidence deep reflection, they show participants' willingness to reflect on their peers' performances. In the PMWN, the teacher-researcher also observed a change in participants' production of comments, which evidenced that they were able to recognize their peers' mistakes and difficulties. Excerpt 2 shows examples of participants identifying specific problems in their peers' performance: ${ }^{2}$

Excerpt 2. Identification of Peers' Mistakes and Difficulties

Don't clear the situation.

In my opinion he should calm when has a conversation.

The conversation breakdown. (PMWN)

There were also positive comments that showed that participants identified good performances, too. Excerpt 3 evidences this:

Excerpt 3. Identification of Peers' Good Performances

The time was apropiate.

Talk with good volume.

She have a good pronunciation. (PMWN)

In the PMWN, there were even some comments in which participants did not only establish if the performance was good or bad, but they went beyond by providing reasons that explain their judgment. Excerpt 4 shows examples of this:

Excerpt 4. Emergent Argumentation

Relevance: Is necessary that the situation is punctual.

Organization: The sentences she used has clear and logical.

Variety: He use a variety of vocabulary. He used pre-fabricated sentences in the performance. (PMWN)

In the first one, the participant did not consider his peers' utterances relevant because the situation that framed the conversation was not well established. In the second one, the

1 The names of the participants were replaced by $\mathrm{S}$ and a number.

2 Excerpts were written as participants produced them, so they contain mistakes. 
The Influence of Peer Assessment and the Use of Corpus for the Development of Speaking Skills in In-Service Teachers

participant explained that the speech of the classmate approved the organization criterion because it was clear and ordered in a logical way. In the last one, the participant argued that the criterion of variety was accomplished because the speaker incorporated various pre-fabricated sentences to enrich his speech, the use of the pre-fabricated sentences was confirmed in the video recording.

Subcategory 1.2: Use of compensatory strategies. The teacher-researcher noticed that participants could communicate despite the language limitations associated with their current language level. The teacher-researcher reflected on this phenomenon in the journal as can be seen in Excerpt 5:

Excerpt 5. Use of Strategies to Ensure Interaction

An important aspect of their spoken productions was that participants were able to interact in the conversation. Most of them were able to adapt their speech to the emerging unexpected situations such as when the partner did not produce the exact sentence that was planned or when a classmate from the audience made a joke. (Teacher-researcher's journal)

The teacher-researcher found that to overcome emerging challenges in communication, participants used what Thornbury (2008) called compensatory strategies. According to this author, compensatory strategies are actions that speakers undertake in order to ensure the transmission of a message and maintain the interaction when they do not know or do not remember the exact grammar that they need. In this inquiry, participants used some of the compensatory strategies described by Thornbury. Furthermore, the teacher-researcher observed that participants used other strategies to avoid communication breakdown, so she included them in the list of compensatory strategies. Table 3 shows the number of times in which each compensatory strategy was used during the intervention. The ones with white background are those described by Thornbury while the ones with grey background correspond to other compensatory strategies that participants used in response to the implementation.

The use of the compensatory strategies allowed participants to achieve communication in L2 by overcoming their limitations in the use of the language. This can be seen in Excerpts 6 and 7:

Excerpt 6. Use of Approximation in L2

S14: Oh, dear God! I lost five subjects. I lost math, I lost English, I lost chemistry, I lost biology and religion. (Video-recording transcription)

Excerpt 6 shows S14's use of the approximation strategy. In this excerpt, S14 produced the word lost instead of fail which would have been more appropriate for this context. Both words were similar in meaning which enabled the communication to occur. Excerpt 7 evidences a combination of three compensatory strategies, namely, omission (three spaced dots), avoidance (italics), and approximation in L2 (underline): 
Excerpt 7. Use of Omission, Avoidance and Approximation in L2

S7: He was ... since a long time... I have 10 years... I remember when I was a child I have a dog and now he . .. death. (Video-recording transcription)

Table 3. Use of Compensatory Strategies

\begin{tabular}{||l|c||}
\hline Approximation in L2 & 12 \\
\hline Translation & 4 \\
\hline Omission & 3 \\
\hline Appealing for help & 3 \\
\hline Approximation to an L1 expression & 2 \\
\hline Word coinage & 1 \\
\hline Avoidance & 1 \\
\hline Paralinguistics & 1 \\
\hline Foreignizing & 0 \\
\hline All-purpose words & 0 \\
\hline Circumlocution & 0 \\
\hline Total & $\mathbf{2 7}$ \\
\hline
\end{tabular}

Note: Taken from the analysis of the video recordings.

In Excerpt 7, S7 started conveying a message omitting the unknown words. Later, he decided to reword the message which entailed the use of the avoidance strategy. Next, S7 approximated the verb have that should have been conjugated in past. Finally, S7 produced the word death to approximate the appropriate wording that should have been is dead.

Subcategory 1.3: Construction of a personalized version of the corpus. The teacher-researcher found that participants modified some expressions of the corpus by removing words (this phenomenon was called "simplification"). Participants also added one comforting expression to the corpus (this phenomenon was called "addition"). Table 4 shows the new and simplified expressions that participants used in their spoken productions. 
The Influence of Peer Assessment and the Use of Corpus for the Development of Speaking Skills in In-Service Teachers

Table 4. New and Adapted Expressions of the Corpus

\begin{tabular}{||l|l|l|c||}
\hline \multicolumn{1}{|c|}{ Corpus } & \multicolumn{1}{|c||}{ Personalization } & \multicolumn{1}{c|}{ Feature } & Use \\
\hline $\begin{array}{l}\text { Your (person) is in a better } \\
\text { place now. }\end{array}$ & $\begin{array}{l}\text { Your (person) is in } \\
\text { a better place. }\end{array}$ & Simplification & 1 \\
\hline & Take it easy. & Addition & 1 \\
\hline I am very sorry for your loss. & I am sorry. & Simplification & 1 \\
\hline Don't worry about it! & Don't worry! & Simplification & 4 \\
\hline
\end{tabular}

Note: Taken from the analysis of video recordings

These modifications and additions suggest that participants personalized the corpus, which evince that they did not use it in an unreflected way. Besides, participants' comments in the PMWN evidenced that the corpus fostered language variety as can be seen in Excerpt 8:

Excerpt 8. Expansion of Participants' Vocabulary Range

She know the diferents words.

He has much vocabulary and your conversation is very expensive.

He used many words for the conversation. (PMWN)

\section{Category 2: Emergence of Detrimental Traits}

PA and corpus also resulted in two traits that limited the development of SIS.

Subcategory 2.1: Underassessment. Serrano and Cebrián de la Serna (2011) defined underassessment as a phenomenon in which learners assess their peers under the assessment that the teacher would produce. This situation was evidenced especially at the beginning of the implementation of the project. Only four "no" marks throughout the complete pedagogical implementation evinced participants' resistance to provide low scores. When their peers do not perform well, participants preferred to mark "partially" rather than "no," as can be seen in Table 5 .

The "no" marks appeared in the last checklists, by the end of the pedagogical intervention.

Subcategory 2.2: Dependency on the corpus. When analyzing the video recordings, the teacher-researcher observed that participants constantly interrupted their speaking to consult the written corpus. This suggested that they did not learn the contents in the corpus during the time of the implementation. Evidence of this was found in the journal where the teacher-researcher wrote: 
Excerpt 9. Assessment of "Fluency" in the Journal

Participants need to practice the corpus because they have not acquired the expressions yet. They still require support to use the expressions. (Teacher-researcher's journal)

Table 5. Participants' Assessment Patterns

\begin{tabular}{||l|c|c|c||}
\hline & Yes & Partially & No \\
\hline Interaction & 28 & 3 & \\
\hline Speaking time & 27 & 2 & 2 \\
\hline Volume & 26 & 5 & \\
\hline Relevance & 26 & 5 & \\
\hline Variety & 24 & 7 & \\
\hline Organization & 24 & 7 & \\
\hline Linking words & 21 & 9 & 1 \\
\hline Fluency & 20 & 10 & 1 \\
\hline Accuracy & 19 & 12 & \\
\hline Pronunciation & 15 & 16 & \\
\hline Total of opinions & $\mathbf{2 3 0}$ & $\mathbf{7 6}$ & 4 \\
\hline
\end{tabular}

Note: Taken from the analysis of checklists

Although the corpus helped participants expand their vocabulary range, it limited their spontaneity and fluency.

\section{Limitations}

Although this research study presented interesting results, a number of limitations were evident. Firstly, the training and practice that participants carried out in regard to PA and the use of the corpus were not enough to reduce their resilience to provide low scores when necessary, neither to empower them to use the corpus independently, without the support of their notes, classmates, or teacher. According to Ericsson, Krampe, and Tesch-Römer (1993), higher levels of performance are acquired slowly as a result of a long time practicing, so more practice time might have been needed to obtain better results with the implementation of PA and corpus. 
The Influence of Peer Assessment and the Use of Corpus for the Development of Speaking Skills in In-Service Teachers

Secondly, when using checklists, there should not be room for partial judgments, the person achieved the criteria or not; if there is a "partially" option, learners will tend to select this in order to avoid being rude with their peers, as occurred in this study. As a result, a lack of critical thinking will be perpetuated. Finally, when using the PMWN, as it was applied in this study, learners need to be trained in how to produce pieces of advice since they may lack the required language (vocabulary and structures), or they may not know how to do it politely, avoiding sounding rude and/or threatening (lack of knowledge of the register and language function). The lack of this knowledge may cause learners to limit their comments to avoid being rude with their classmates, as also occurred in this study.

\section{Conclusions}

As a result of the data analysis process, the teacher-researcher could answer the research question that guided the development of the study. In this sense, the teacher-researcher found that the PA and corpus influenced the development of participants' SIS in the following two ways:

On the one hand, PA and corpus encouraged participants to develop three strategies to enhance their SIS productions, namely, willingness to improve, use of compensatory strategies, and construction of a personalized version of the corpus. These strategies provoked participants to reflect on the strengths and weaknesses of their spoken productions, overcome language barriers to achieve communication, and expand the range of vocabulary and structures that they were able to use in their spoken productions.

On the other hand, PA and corpus produced the emergence of two detrimental traits, namely, underassessment and dependency on the corpus. These traits impeded participants from delving further into the analysis of their spoken production and affected their fluency and spontaneity when speaking. However, more practice might be a solution to prevent these difficulties from appearing.

\section{References}

Ahangari, S., Rassekh-Alqol, B., \& Akbari, L. A. (2013). The effect of peer assessment on oral presentation in an EFL context. International Journal of Applied Linguistics \& English Literature, 2(3), 45-53. http://dx.doi.org/10.7575/aiac.ijalel.v.2n.3p.45.

Bennett, G. R. (2010). Using corpora in the language learning classroom: Corpus linguistics for participants. Michigan ELT, 1-22. Retrieved from http://www.international.ucla.edu/media/ files/Using-corpora-in-the-language-learning-classroom-Corpus-linguistics-for-teachers-m y-atc.pdf?AspxAutoDetectCookieSupport $=1$.

Chu, H., \& Wang, R. (2011). Oral and written competence of Chinese foreign language learners in terms of lexical chunks. International Journal of English Linguistics, 1(1), 223-226. http://dx.doi.org/10.5539/ijel.v1n1p223. 
Corbin, J., \& Strauss, A. (2008). Basics of qualitative research: Grounded theory procedures and techniques (3rd ed.). Thousand Oaks, CA: Sage Publications.

Council of Europe. (2014). Common European Framework of Reference for Languages: Learning, teaching, assessment. Retrieved from http://www.coe.int/t/dg4/linguistic/source/framework_en.pdf.

Creswell, J. W. (2009). Research design: Qualitative, quantitative, and mixed methods approaches (3rd ed.). Thousand Oaks, CA: Sage Publications.

Ericsson, K. A., Krampe, R. T., \& Tesch-Römer, C. (1993). The role of deliberate practice in the acquisition of expert performance. Psychological Review, 100(3), 363-406. http://dx.doi.org/10.1037/0033-295X.100.3.363.

Glasson, T. (2009). Improving student achievement: A practical guide to assessment for learning. Carlton, AU: Curriculum Corporation.

Gómez, D. (2014). The impact of peer and self-assessment on teenage B2 students'use of present perfect simple, present perfect continuous and past perfect simple in their spontaneous spoken productions (Master's thesis). Universidad de La Sabana, Bogotá, Colombia.

Koshy, V. (2005). Action research for improving practice: A practical guide. London, UK: Paul Chapman Publishing.

Lim, P. T. H. (2007, May). Action research for teachers: A balanced model. Proceeding of the Redesigning Pedagogy: Culture, Knowledge and Understanding Conference 2007, Singapore. Retrieved from http:/ / citeseerx.ist.psu.edu/viewdoc/download?doi=10.1.1.570.1170\&rep=rep1\&type=pdf.

McMillan, J. H., \& Schumacher, S. (2009). Research in education: Evidence-based inquiry (7th ed.). London, UK: Pearson Education.

Moudraia, O. (2001). Lexical approach to second language teaching. ERIC Digest. Retrieved from http://www.cal.org/index.php/content/download/1546/16373/file/LexicalApproachtoSe condLanguageTeaching.pdf.

Sagor, R. (2000). Guiding school improvement with action research. Alexandria, VA: Association for Supervision and Curriculum Development.

Serrano, J., \& Cebrián de la Serna, M. (2011). Study of the impact on student learning using the eRubric tool and peer assessment. In A. Méndez-Vilas (Ed.), Education in a technological world: Communicating current and emerging research and technological efforts (pp. 421-427). Badajoz, ES: Formatex Research Center.

Suzuki, T. (2008, August). A corpus-based study of the speech act of "comforting": Naturalness and appropriateness for English language teaching. Paperpresented at the 13th PAAL Conference, University of Hawaii, Manoa, USA. Retrieved from http://www.f.waseda.jp/toshisuz/ paal2008handout.pdf.

Suzuki, T. (2009a). A study of lexicogrammatical and discourse strategies for 'suggestion' with the use of the English speech act corpus. Retrieved from http://dspace.wul.waseda.ac.jp/ dspace/bitstream/2065/29661/1/BunkaRonshu_34_Suzuki.pdf.

Suzuki, T. (2009b). How do American university students "invite" others? A corpus- based study of linguistic strategies for the speech act of "invitations". The Cultural Review, 4(35), 85-106. Retrieved from http://www.waseda.jp/w-com/quotient/publications/pdf/bun35_04.pdf. 
The Influence of Peer Assessment and the Use of Corpus for the Development of Speaking Skills in In-Service Teachers

Suzuki, T. (2010). A corpus-linguistic approach to the verbal realization of "comforting". The Cultural Review, 4(36), 81-103. Retrieved from http://www.waseda.jp/w-com/quotient/ publications/pdf/bun36_04.pdf.

Suzuki, T. (2011). Children's pragmatic competence: A case study of English speech acts performed by American children. The Cultural Review, 3(38), 55-73. Retrieved from http://www.waseda.jp/w-com/quotient/publications/pdf/bun38_03.pdf.

Thornbury, S. (2008). How to teach speaking. Harlow, UK: Pearson Education.

Valcarcel, D. (2009). Action research essentials. San Francisco, CA: Jossey-Bass.

Willis, D., \& Willis, J. (2012). Doing task-based teaching. Oxford, UK: Oxford University Press.

\section{The Author}

Mary Mily Gómez Sará holds a Master in English language teaching with an emphasis on autonomous learning environments from Universidad de La Sabana (Colombia). 


\section{Appendix 1: Questionnaire $1^{3}$}

Dear participants,

I invite you to answer this questionnaire whose aim is to explore your learning interests and needs. Your answers will help me improve the development and content of my classes. Feel free to write your opinions and experiences in detail. It is important to note that your responses will be treated anonymously.

\section{Estimated time of development: $5 \mathrm{~min}$.}

1. Which skill have you developed the most in your process of learning English? Listening _ Speaking _ _ Reading _ _ Writing _

2. Why do you think that you have developed this skill more?

3. Which skill have you developed the least in your process of learning English? Listening _ S Speaking _ _ Reading _ _ Writing _

4. Why do you think that you have developed this skill less?

5. Which skill would you like to emphasize during the English classes?
Listening _
Speaking _
Reading _
Writing 
The Influence of Peer Assessment and the Use of Corpus for the Development of Speaking Skills in In-Service Teachers

\section{Appendix 2: Focus Group}

\section{Dear participants.}

This is the guideline to participate in a group interview that aims to explore the difficulties that you find when doing oral productions. This interview was designed based on your responses to a questionnaire developed in a previous session. I invite you to complete the self-assessment format below and then participate in the discussion. Your contributions will help me better understand your learning interests and needs. The interview will be recorded, transcribed, and then analyzed, but your personal information will be always treated anonymously.

Please evaluate your speaking skills from 1 to 5 , where 1 represents low mastery of skill and 5 total dominance.

Estimated time of development: $15 \mathrm{~min}$.

\begin{tabular}{|c|c|c|c|c|c|c|}
\hline & & 1 & 2 & 3 & 4 & 5 \\
\hline 1 & Have a clear understandable pronunciation. & & & & & \\
\hline 2 & $\begin{array}{l}\text { Use appropriate patterns of stress, rhythm, and } \\
\text { intonation. }\end{array}$ & & & & & \\
\hline 3 & $\begin{array}{l}\text { Use appropriate word variation such as verb } \\
\text { conjugation, adjective, nouns, etc. }\end{array}$ & & & & & \\
\hline 4 & Produce language following the grammatical structure. & & & & & \\
\hline 5 & $\begin{array}{l}\text { Have a wide range of vocabulary that allows } \\
\text { participating in conversations of diverse topics. }\end{array}$ & & & & & \\
\hline 6 & $\begin{array}{l}\text { Use formal or informal language according to the } \\
\text { context and situation. }\end{array}$ & & & & & \\
\hline 7 & Provide arguments that support my ideas. & & & & & \\
\hline 8 & Organize my speech in a logical way. & & & & & \\
\hline 9 & $\begin{array}{l}\text { Say a same idea in a different way (rephrase, } \\
\text { reformulate). }\end{array}$ & & & & & \\
\hline 10 & $\begin{array}{l}\text { Follow the topic of a conversation and participate } \\
\text { accordingly. }\end{array}$ & & & & & \\
\hline
\end{tabular}




\section{Appendix 3: Questionnaire 2}

Dear participants,

This is a one-question questionnaire that aims to identify the language function that you use the most when interacting with your students in situations different from the class.

\section{What are language functions?}

Speakers produce language with a communicative intention. That intention or purpose is called function. There are many language functions such as greeting, thanking, suggesting, comforting, apologizing, etc. A function can be expressed through different utterances. For instance, the expressions "You are very kind", "I am very thankful", "Thank you for..." have as their function to offer thanks.

\section{Instructions:}

1. Highlight the five functions that you use the most when talking to your students in situations different from the class.

2. Then, number the functions that you selected considering that 1 is the most used and 5 the least used.

_ Clarify something (I mean...)

Thank (You're very kind...)

Assume responsibilities (I will do it)

_ Conclude (Finally...)

Blame someone (It was you...)

_ Giving advice (I suggest you...)

__ Giving instructions (Sit down, please)

__ Giving opinions (I think...)

__ Deduct information (This means that...)

__ Apologize (I am very sorry...)

Praise someone (You are so beautiful...)

Agree (Of course...)

Disapprove of something (I do not like that...)

Express anxiety (That really stresses me...) 
The Influence of Peer Assessment and the Use of Corpus for the Development of Speaking Skills in In-Service Teachers

_ Express displeasure (I dislike...)

__ Express obligation (I have to...)

__ Express preference (I like... more than...)

__ Express probability (Maybe...)

_ Express surprise (Really?)

_ Congratulate someone (Nice work)

__ Insinuate something (It would be good if...)

__ Invite someone (Do you want to go to...?)

_ Offer something (How about ...?)

__ Forbid something (Do not do that)

_ Complain (This is very complicated)

_ Comfort someone (Do not worry)

__ Require something (Can you help me with...)

__ Suggest something (What if...?) 


\section{Appendix 4: Peer Assessment Checklist}

1. Observe the conversation of your classmates.

2. Answer the questions by marking a tick $(\boldsymbol{})$ in the column that corresponds.

\begin{tabular}{|c|c|c|c|c|c|}
\hline & Assessment Criteria & Yes & Partially & No & Comments \\
\hline Content & $\begin{array}{l}\text { 1. Relevance of the message: } \\
\text { Was the message of the } \\
\text { speaker relevant to the } \\
\text { listener? }\end{array}$ & & & & \\
\hline \multirow{4}{*}{ Delivery } & $\begin{array}{l}\text { 2. Speaking time: Did the } \\
\text { speakers talk for at least } 5 \\
\text { minutes? }\end{array}$ & & & & \\
\hline & $\begin{array}{l}\text { 3. Volume: Did the speakers } \\
\text { talk in an audible volume? }\end{array}$ & & & & \\
\hline & $\begin{array}{l}\text { 4. Fluency, pauses, and } \\
\text { rhythm: Did the speakers } \\
\text { talk with an appropriate } \\
\text { balance between fluency } \\
\text { and pauses? }\end{array}$ & & & & \\
\hline & $\begin{array}{l}\text { 5. Pronunciation: Was the } \\
\text { pronunciation } \\
\text { understandable? }\end{array}$ & & & & \\
\hline \multirow{2}{*}{ Organization } & $\begin{array}{l}\text { 6. Organization: Was the } \\
\text { message organized in a } \\
\text { logical way? }\end{array}$ & & & & \\
\hline & $\begin{array}{l}\text { 7. Linking words: Did the } \\
\text { speakers use linking words } \\
\text { to connect their ideas? }\end{array}$ & & & & \\
\hline \multirow{2}{*}{ Language } & $\begin{array}{l}\text { 8. Accuracy: Were the } \\
\text { sentences grammatically } \\
\text { correct? }\end{array}$ & & & & \\
\hline & $\begin{array}{l}\text { 9. Variety: Did each speaker use } \\
\text { at least } 5 \text { prefabricated } \\
\text { sentences from the corpus? }\end{array}$ & & & & \\
\hline
\end{tabular}


The Influence of Peer Assessment and the Use of Corpus for the Development of Speaking Skills in In-Service Teachers

\begin{tabular}{|c|c|c|c|c|c|}
\hline & Assessment Criteria & Yes & Partially & No & Comments \\
\hline Interaction & $\begin{array}{l}\text { 10. Interaction: Were the } \\
\text { interventions of the speakers } \\
\text { related? }\end{array}$ & & & & \\
\hline
\end{tabular}




\section{Appendix 5: “Plus, minus, and what's next?" Form}

1. Observe the conversation of your classmates.

2. Fill the table considering the assessment criteria.

\begin{tabular}{||l|c|c|c||}
\hline \multirow{2}{*}{\begin{tabular}{|l||} 
Assessment Criteria \\
\cline { 2 - 4 }
\end{tabular}} & Plus (+) & Minus (-) & What's next? \\
\hline $\begin{array}{l}\text { Relevance of the message } \\
\text { Speaking time }\end{array}$ & Bad aspects & $\begin{array}{c}\text { What to practice } \\
\text { (advice) }\end{array}$ \\
Volume & & \\
Fluency, pauses, and & & \\
rhythm & & \\
Pronunciation & & \\
Organization & & \\
Linking words & & \\
Accuracy & & & \\
Variety & & \\
Interaction & & & \\
\hline
\end{tabular}


The Influence of Peer Assessment and the Use of Corpus for the Development of Speaking Skills in In-Service Teachers

\section{Appendix 6: Sample of the Corpus About Comforting}

\begin{tabular}{|c|c|c|c|c|c|c|c|c|c|}
\hline \# & $\begin{array}{c}\text { Sub- } \\
\text { Function }\end{array}$ & Corpus & Death & $\begin{array}{c}\text { Break } \\
\text { Up }\end{array}$ & $\begin{array}{l}\text { Difficult } \\
\text { Situation }\end{array}$ & $\begin{array}{c}\text { Unfavo- } \\
\text { rable } \\
\text { Event }\end{array}$ & $\begin{array}{c}\text { Sickness / } \\
\text { Injury }\end{array}$ & $\begin{array}{l}\text { Failure } \\
\text { In Test }\end{array}$ & $\begin{array}{l}\text { Acci- } \\
\text { dent }\end{array}$ \\
\hline 1 & Soother & $\begin{array}{l}\text { (Person) is } \\
\text { okay. }\end{array}$ & $\mathrm{X}$ & & & & & & \\
\hline 2 & Advice & $\begin{array}{l}\text { (Verb) will } \\
\text { make you feel } \\
\text { better. }\end{array}$ & & $\mathrm{X}$ & & & & & \\
\hline 3 & Sympathy & Are you okay? & $\mathrm{X}$ & $\mathrm{X}$ & & & & & $\mathrm{X}$ \\
\hline 4 & $\begin{array}{l}\text { Offer of } \\
\text { support }\end{array}$ & $\begin{array}{l}\text { Can I do } \\
\text { anything to } \\
\text { help you feel } \\
\text { better? }\end{array}$ & $\mathrm{X}$ & & & & $\mathrm{X}$ & & \\
\hline 5 & Advice & Cheer up. & & $\mathrm{X}$ & $\mathrm{X}$ & $\mathrm{X}$ & & $\mathrm{X}$ & \\
\hline 6 & Advice & Don't cry. & $\mathrm{X}$ & $\mathrm{X}$ & $\mathrm{X}$ & & & & $\mathrm{X}$ \\
\hline 7 & Advice & $\begin{array}{l}\text { Don't be so } \\
\text { nervous. }\end{array}$ & & & & & & $\mathrm{X}$ & \\
\hline 8 & Advice & $\begin{array}{l}\text { Don't forget } \\
\text { school break is } \\
\text { coming up. }\end{array}$ & & & $\mathrm{X}$ & $\mathrm{X}$ & & $\mathrm{X}$ & \\
\hline 9 & Advice & $\begin{array}{l}\text { Don't worry } \\
\text { about it! }\end{array}$ & & $\mathrm{X}$ & $\mathrm{X}$ & & & $\mathrm{X}$ & \\
\hline 10 & $\begin{array}{l}\text { Encourage- } \\
\text { ment }\end{array}$ & $\begin{array}{l}\text { Everything is } \\
\text { going to be } \\
\text { fine. }\end{array}$ & $\mathrm{X}$ & $\mathrm{X}$ & $\mathrm{X}$ & $\mathrm{X}$ & & & $\mathrm{X}$ \\
\hline 11 & $\begin{array}{l}\text { Encourage- } \\
\text { ment }\end{array}$ & $\begin{array}{l}\text { Everything will } \\
\text { be all right. }\end{array}$ & $\mathrm{X}$ & $\mathrm{X}$ & $\mathrm{X}$ & $\mathrm{X}$ & & & $\mathrm{X}$ \\
\hline 12 & $\begin{array}{l}\text { Encourage- } \\
\text { ment }\end{array}$ & $\begin{array}{l}\text { Everything will } \\
\text { be okay. }\end{array}$ & $\mathrm{X}$ & $\mathrm{X}$ & $\mathrm{X}$ & $\mathrm{X}$ & & & $\mathrm{X}$ \\
\hline 13 & $\begin{array}{l}\text { Encourage- } \\
\text { ment }\end{array}$ & $\begin{array}{l}\text { Everything } \\
\text { works out in } \\
\text { the long run, I } \\
\text { promise. }\end{array}$ & & $\mathrm{X}$ & $\mathrm{X}$ & $\mathrm{X}$ & & & \\
\hline 14 & $\begin{array}{l}\text { Offer of } \\
\text { support }\end{array}$ & $\begin{array}{l}\text { I am here for } \\
\text { you. }\end{array}$ & $\mathrm{X}$ & & $\mathrm{X}$ & & $\mathrm{X}$ & & $\mathrm{X}$ \\
\hline
\end{tabular}


Mary Mily Gómez Sará

\begin{tabular}{|c|c|c|c|c|c|c|c|c|c|}
\hline$\#$ & $\begin{array}{c}\text { Sub- } \\
\text { Function }\end{array}$ & Corpus & Death & $\begin{array}{c}\text { Break } \\
\text { Up }\end{array}$ & $\begin{array}{l}\text { Difficult } \\
\text { Situation }\end{array}$ & $\begin{array}{c}\text { Unfavo- } \\
\text { rable } \\
\text { Event }\end{array}$ & $\begin{array}{c}\text { Sickness/ } \\
\text { Injury }\end{array}$ & $\begin{array}{l}\text { Failure } \\
\text { In Test }\end{array}$ & $\begin{array}{l}\text { Acci- } \\
\text { dent }\end{array}$ \\
\hline 15 & Sympathy & $\begin{array}{l}\text { I am really sorry } \\
\text { about the loss } \\
\text { in your family. }\end{array}$ & $X$ & & & & & & \\
\hline 16 & Sympathy & $\begin{array}{l}\text { I am so sorry } \\
\text { things didn't } \\
\text { work out } \\
\text { between you } \\
\text { two. }\end{array}$ & & $\mathrm{X}$ & & & & & \\
\hline 17 & Sympathy & $\begin{array}{l}\text { I am so sorry to } \\
\text { hear about your } \\
\text { (mom, etc.) } \\
\text { dying. }\end{array}$ & $\mathrm{X}$ & & & & & & \\
\hline 18 & Sympathy & $\begin{array}{l}\text { I am sorry to } \\
\text { hear about your } \\
\text { (person). }\end{array}$ & $\mathrm{X}$ & & & & & & \\
\hline 19 & Sympathy & $\begin{array}{l}\text { I am sorry to } \\
\text { hear that. }\end{array}$ & $\mathrm{X}$ & & & & $\mathrm{X}$ & & $\mathrm{X}$ \\
\hline 20 & Advice & $\begin{array}{l}\text { I am telling you } \\
\text { to break up } \\
\text { with her. }\end{array}$ & & $\mathrm{X}$ & & & & & \\
\hline
\end{tabular}


The Influence of Peer Assessment and the Use of Corpus for the Development of Speaking Skills in In-Service Teachers

\section{Appendix 7: Sample of a Video Recording Transcription}

Date: Thursday, November 7th, 2013 (Session 3)

\section{Role Play 1}

S10: Hello, teacher. How are you?

S9: Bien[fine] or what.

S10: (Laughs).

S9: What's happen?

S10: Teacher, please me with my son. My son is very...lazy.

S9: Very lazy? Yes.

(Participants joke a little)

S9: What's happen? Fabiancito.

S4: I am very lazy because I do not understand...

S9: In what mat..?

S4: In math.

S9: In mathematics?

S4: Yes. I always...I always...I always...fail.

S9: You know because?

S4: I...I like...now, the mathematics, but I do not understand.

S9: You do not understand mathematics.

S10: Teacher, please help us.

S9: OK. Don't forget school break is coming up. Take it easy. Ok?

S10. Ok. Thanks you teacher. 


\section{Appendix 8:Teacher-Researcher's Journal}

\begin{tabular}{|c|c|c|c|c|}
\hline Session: & Date: & Time: & $\begin{array}{l}\text { Implementation } \\
\text { Stage: }\end{array}$ & \# participants: \\
\hline \multicolumn{5}{|c|}{ Summary of the Class Activities: } \\
\hline \multicolumn{2}{|c|}{ Description of the activity with the corpus } & \multicolumn{3}{|c|}{$\begin{array}{l}\text { Analyzing participants' response to the activity with the } \\
\text { corpus }\end{array}$} \\
\hline \multicolumn{2}{|c|}{ Description of the SIS activity } & \multicolumn{3}{|c|}{ Analyzing participants' response to the SIS task } \\
\hline \multicolumn{2}{|c|}{ Description of the PA activity } & \multicolumn{3}{|c|}{ Analyzing participants' response to $\mathrm{PA}$} \\
\hline
\end{tabular}

